\title{
Lutheranism and the Nordic Welfare States in a Gender Perspective
}

\section{Af Pirjo MarkKola}

Dev er behov for at sette fokus pà forboldet mellem lutheranisme, velferd og køn. På rummet mellem den religionsblinde kønsforskning om velfardsstaten og den konsblinde forskning om lutheranisme og velfardsstat.

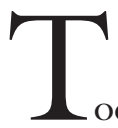

oday there are two lively but rather separate discussions on the welfare states in the Nordic countries. One concerns the welfare state in a gender perspective; the other is mainly interested in the role of Lutheranism in the Nordic welfare state model. ${ }^{1}$ Interestingly, gender research has a longer and better established tradition while the religious aspect has only recently gained a better foothold in the Nordic academic arena. Both discussions are based on the perceived historical and social dimensions of the Nordic societies, i.e. gender relations on the one hand and a unique religious history on the other.

As far as gender relations are concerned, the Nordic welfare states have often been seen as model states of gender equality. The share of women in the labour force is high and there is an extensive network of social services for children, youth and old people. Women's suffrage in the Nordic countries was gained relatively early - between 1906 (Finland) and 1919 (Sweden) - and today 
the share of women involved in political decision-making is high. Because of these common features it is a general practice to talk about a Nordic model, although recently more attention has been paid to the differences between the various countries (Bergqvist \& al. 1999). The peculiarly Nordic religious history consists of the long tradition of the Evangelical-Lutheran state churches. Lutheranism was an official ideology of the state until the 19th century and even in the $20^{\text {th }}$ century formal state-church relations have been relatively close. Moreover, over 80 per cent of Nordic citizens (ca. 87 per cent in Denmark and Norway, 85 per cent in Finland and 84 per cent in Sweden) are still members of the Evangelical-Lutheran churches (Markkola 2000a). In this respect, too, we share a strong Nordic model.

In this article, I shall attempt to combine these two discussions and point out some new questions that deserve to be studied. I argue that gender research has mainly been "religion-blind" (Hammar 1998), while research on Lutheranism and welfare has mainly been gender-blind. However, these two lines of research could benefit from dialogue, and together they could give a fuller account of the history of the Nordic welfare states in general and the 'Nordic model' in particular. Furthermore, this dialogue needs to be placed in a comparative framework. My aim here is two-fold. Firstly, I will discuss welfare regimes in a gender perspective and suggest ways to incorporate religion into this discussion. Secondly, I will turn to the latest debate on Lutheranism and the welfare state and call for a gender perspective in research in this area. I argue that the relationship between Lutheranism, welfare and gender needs to be studied in a historical perspective if we want to understand the multifaceted history of the Nordic welfare states.

\section{GENDERING WELFARE REGIMES}

The concepts 'welfare state models' and 'welfare regimes' imply a comparative perspective. The extent to which countries sharing the same model are identical or similar is always an issue that needs to be discussed and the criteria has to be defined. Given that gender is a fundamental organising principle of society, one of the key criteria must be the way in which gender relations or gender difference is understood and organised.

One of the best-known and probably most widely used categorisations of the welfare states was formulated by the Danish sociologist Gøsta Esping-Andersen, whose model of welfare regimes (liberal, conservative and social democratic) is either applied or challenged by several scholars (EspingAndersen 1990, Sainsbury 1994). Rather than going into a detailed discussion of his categories, I want to mention one point of criticism central to a gender perspective. The British scholar Jane Lewis argues that from a gender perspective the major part of the comparative work on modern welfare states overlooks two central issues: unpaid work and the mixed economy of welfare provision. By focusing on the relationship between work and welfare these typologies ignore the importance of the unpaid work that is done in providing welfare. The mixed economy of welfare provision, by which Lewis means the interplay of the state, the voluntary sector, the family and the market, has historically been important for understanding women's contribution as providers of welfare. ${ }^{2}$ In the Nordic countries the complex nature of social policy and the provision of welfare has been emphasised by women's historians. Scholars of philanthropy, in particular, have pointed out the importance of the voluntary sector - Ladies' Societies, schools and private institutions (See, for example, Jordansson and Vammen 1998; also Lützen 1998). From the point of view of women, many dimensions of the history of welfare become obvious. 
The mixed economy of welfare provision is one of the fields in which the churches have been historically active. In the 19th and early $20^{\text {th }}$ centuries, Christian social work and deacony (diakonia, service) became important providers of welfare. The first Nordic deaconess institution was founded in 1851 in Stockholm and by the end of the 1860s there were similar institutions established in Denmark, Norway and Finland. The Nordic leaders of the deaconess institutions often presented an idea of a welfare model in which public poor relief together with the philanthropic and religious organisations shared responsibility for the well being of needy people (Markkola 2000b). The interplay of the state, municipalities, the church and (women's) voluntary organisations remains one of the challenges for welfare research in a gender perspective.

The critique by feminist scholars reminds us of the fact that the welfare state is profoundly gendered. According to Jane Lewis, the concept 'welfare regime' must incorporate the relationship between unpaid as well as paid work and welfare. Based on these criteria she identifies 'strong', 'modified' and 'weak' male-breadwinner states (Lewis 1992; Lewis 2000). This is an important step toward integrating a gender perspective into welfare state models. However, the Nordic scholars, for example the Finnish social scientist Raija Julkunen, prefer to speak of families with two breadwinners or a dual-breadwinner model instead of a 'weak' male-breadwinner model. Furthermore, Diane Sainsbury and Birte Siim criticise the male-breadwinner model in two different ways (Julkunen 1999; Siim 2000, 14-17; Sainsbury 1997, 40-44). Sainsbury argues that the strength of the male-breadwinner model is a problematic criterion for comparisons. She suggests an analysis of the dimensions of variation between ideologies based on the male-breadwinner model and an individual model. Although she does not take religious dimensions into consideration, her model is open to them. Birte Siim is more critical towards the concept 'male-breadwinner model.' According to her, there is a tendency to reduce both social policies and paid labour to a single universal logic of the male-breadwinner model. She suggests a more dynamic framework within which to discuss both the structural forces and the role of actors in the formation of the welfare state. An important element of the religious perspective is revealed by Siim, who comments on the ways in which the Danish welfare state is challenged by increasing religious and ethnic heterogeneity. In my opinion the fact that the Nordic welfare states have been built in the circumstances of religious Lutheran homogeneity deserves further attention. Has Lutheranism become an unnoticed or unproblematised element of the Nordic societies?

\section{COMPARISON AND \\ THE NORDIC MODEL}

Comparative research can make the unnoticed and unproblematized aspects of the history of the welfare states visible. The Swedish scholars Klas Åmark and Joakim Palme accentuate the importance of dialogue between scholars representing different comparative approaches (Åmark \& Palme, 1999, 10-12). The Finnish sociologist Solveig Bergman argues that sociologists could gain inspiration from the methods used by historians and anthropologists, who apply synthesising and holistic approaches in cross-national comparisons embracing whole societies (Bergman 2000, 152). In this respect the religious perspective can also elucidate both differences and similarities between various countries. It seems to me that in inter-Nordic comparisons we should pay attention to differences and thus test the limits of the Nordic model, whereas in comparisons between Nordic countries and other countries, Nordic similarities and common features become more pivotal. Again, one of the differences 


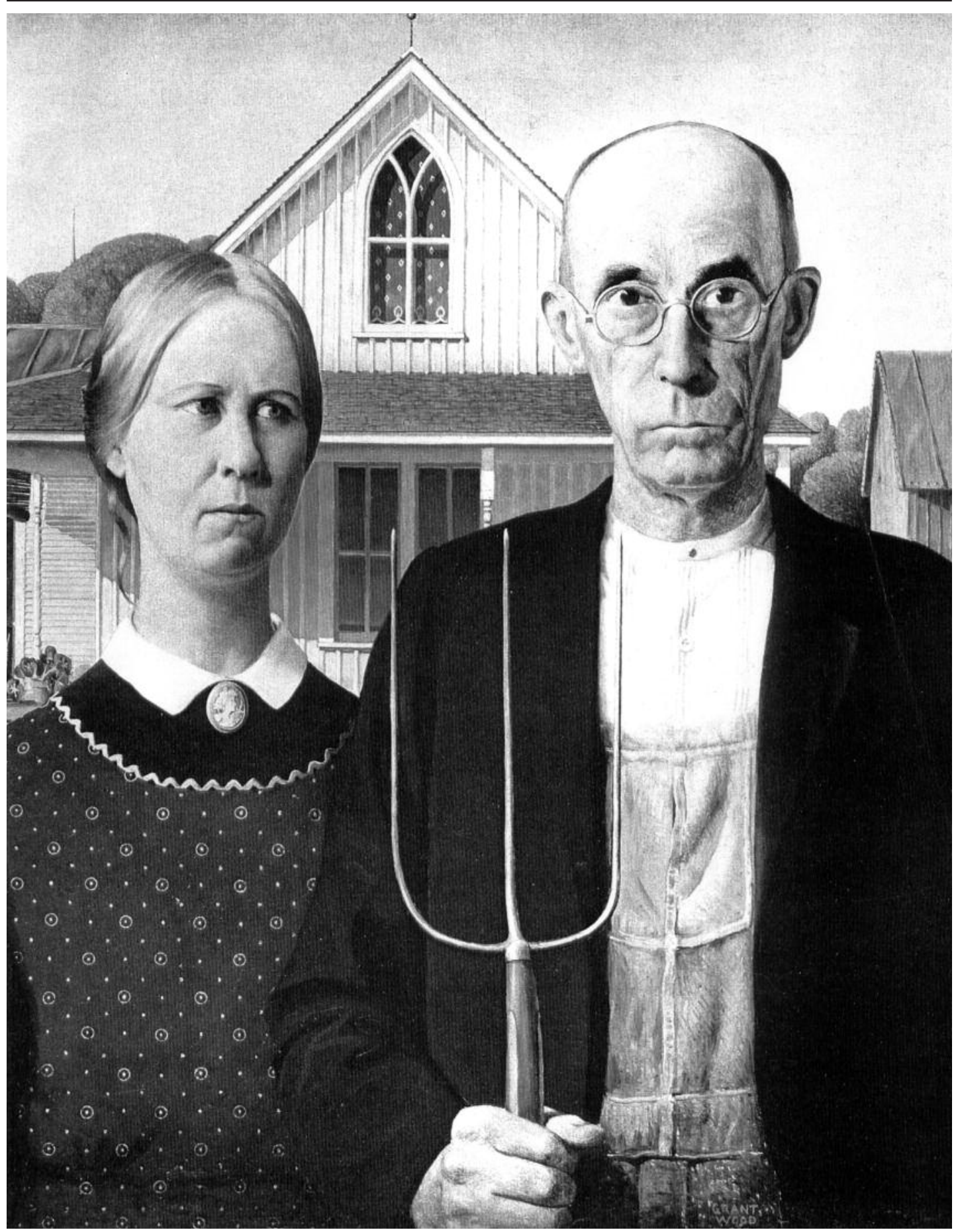

Grant Wood (1892-1942): American Gothic fra 1930. The Art Institute of Chicago

between the Nordic countries and "the rest of the world" is the historical role and the status of the Lutheran churches.
In the Finnish context the Nordic model became more important in the 1990s, especially for women. The gendered division of 
labour in political decision-making has increased women's influence on social policy, education and health care. All of these are core areas of the welfare state. The welfare state provided women with jobs in the 1970s and 1980s, when the public service sector grew very fast. There were new jobs established in education, health care and social services, and vast numbers of women were recruited into the public sector. The 1970s saw the introduction of separate taxation for married couples and at the same time public day-care and other services began to expand in scale. Maternity leaves were extended and paternity leaves were introduced. ${ }^{3}$ From the 1970 s onwards the tie between women and the welfare state became more evident. However, recent studies have shown that the welfare state has not protected women against domestic violence (Julkunen 1999; Heiskanen and Piispa 1998).

In the 1990s the link between women and the welfare state also began to have it's disadvantages. Women in politics have been forced to make painful decisions when faced with cuts in public spending (Kuusipalo 1999; Julkunen 1999). Women have come to the defence of a welfare state that has been blamed for being too expensive and making people lazy and passive. For most Finnish women the welfare state has guaranteed a certain standard of living and made their daily lives a little easier. Many women feel that cutbacks in public spending are taken from the purses of women and that they will be the losers. In this respect it is really interesting to note, that during and after the economic recession of the 1990s, the Evangelical-Lutheran Church of Finland openly defended the Nordic welfare state model. In 1999 the Bishops published a statement on the future of the welfare society. One of their declarations was: "We must not give up the Nordic achievement of a form of society, which is characterised by a broad social responsibility." Furthermore, they argued that the welfare state is important for the church because it is root- ed in its own tradition (Salonen, Kääriäinen and Niemelä; Towards the Common Good 1999). Women and the church found themselves in defending the Nordic welfare state model.

\section{LUTHERANISM AND WELFARE}

Lutheranism, as represented by the Evangelical-Lutheran churches, is an important aspect of Nordic history. For historical reasons, the influence of Lutheranism is a wider cultural and mental phenomen than a direct impact of the church. Strong ties between the church and the state in the Nordic countries date back to the Middle Ages and, in particular, to the Lutheran Reformation, which reached Scandinavia in the 1520 s and 1530s. The churches became an integrated part of the governing of the state. On the one hand, the clergy represented the state on a local level; on the other, religious confession and church order had political importance. The Finnish church historian Juha Seppo has pointed out that fixed state-church relations have defined the state itself. The religious uniformity of the people has been the social basis of the system (Seppo 1994, 37).

The Norwegian church historian Dag Thorkildsen underlines the strength and adaptability of the state church system. In terms of national identities, he argues, the state churches represent a historical continuity. He also points out similarities between some principles of Lutheranism and the Nordic welfare states. Two central ideas in Lutheranism - daily work as the fulfilment of God's vocation, and a priesthood of all believers - correspond to the principles of full employment and social security. According to Thorkildsen "'a priesthood of all believers' promoted a culture of equality, where obvious wealth and large social differences were not acceptable because fundamentally all individuals are equal and have the same worth." (Thorkildsen 1997, 159) A similar correspondence between 
Lutheran visions of good society and Nordic visions of the welfare state has been suggested by the Finnish theologian Antti Raunio. He argues that, in contrast to German Lutheranism, it has been characteristic of the Nordic Lutheran churches to emphasise the wide social responsibilities of the state. There is a long tradition in the Nordic countries of thinking that the wellbeing of an individual is the responsibility of the state, and for that reason neither liberalism nor neoliberalism have been very successful. Raunio concludes that it is no coincidence that the Nordic welfare states and a hegemonous Lutheran tradition are found in the same part of the world (Raunio 1999, 78-84). The Danish historian Uffe Østergård is even more provocative when he asks if "the social democratic parties, regardless of what party programmes and generations of party members have said, are the products of secularised Lutheranism rather than democratised socialism" (Øster-gård 1997, 69).

The Danish political scientist Tim Knudsen argues that the universalistic nature of the Nordic welfare states and the strong role of local administration cannot be understood without a long historical perspective. According to him the universalist welfare state builds on a long tradition in the fields of social policy, education and health care. This tradition can be found in the history of the Lutheran state churches. The churches have clearly made an important contribution by strengthening the state, i.e. by increasing 'state capacity'. However, Knudsen leaves open the question if the Scandinavian Lutheran religion has also had implications for the building of the modern welfare states (Knudsen 2000, 20-61).

Lutheranism has certainly influenced the ways in which the nature of social legislation took shape in the Nordic countries, although I would be very cautious about drawing further conclusions without a careful analysis of the development of the statechurch relations in the fields of poor relief, health care and social security. Despite the shared theological foundations, the Nordic Lutheran churches have also expressed different views both in the course of history and in various national contexts. For example, in 1958 the Finnish Bishop Eino Sormunen published a small book on the welfare state. He cited the Norwegian Bishop Eivind Berggrav who had criticised the welfare state for being demonic and for not tolerating any other providers of welfare, including home and family care. According to Sormunen the opinions of Berggrav were exaggerated but a useful word of warning about the possible disadvantages of state welfare policies. Sormunen's own view of the welfare state was much more positive and he called for more dialogue and co- $^{-}$ operation between the state and the church in the provision of public welfare. However, women seemed to constitute a problem for the Finnish churchman, too. He expressed his concern regarding the institutions which were replacing women's caring work at home (Sormunen 1958, 20-27). The Norwegian Bishop's disapproval and the Finnish Bishop's concern suggest that Lutheranism and the welfare state form an intriguing and complicated picture which deserves to be analysed in a gender perspective.

\section{GENDERING LUTHERANISM}

Scholars who refer to the role of the Evangelical-Lutheran state churches or Lutheranism seem to pay very little attention to gender difference and the gendered nature of social and political institutions. In this respect I find it useful to cite Bente Rosenbeck's brief comment on Protestant ideology which has "created a more benevolent climate for the education of girls and for women's rights movements" even though it is "far from woman-friendly" (Rosenbeck 1998, 348). This is an important point of departure for future research. First of all, I want to revert to the two pillars of Lutheran theology pointed out by Dag Thorkildsen. 
The first one (daily work as the fulfilment of God's vocation) is particularly important for the formation of gender relations and the ways in which Lutheranism has defined male and female vocations. The issue of Lutheran theology has been introduced in Scandinavian debates on the history of the women's movement by the Swedish historian Inger Hammar, who has coined the phrase 'religion blind women's history'. She studies the Lutheran context of the early Swedish women's movement and argues that the movement of the nineteenth century cannot be understood without placing religious discourse at the core of the analysis. She discusses the Lutheran view of calling and its implications for women. In Martin Luther's view society was divided into three estates: ecclesia - the church, politia - the state and oeconomia - the household. A woman's vocation - calling - was to be lived out in the estate of oeconomia: the estates of the state and the church were reserved for men or, at best, women could exercise their influence through men. A woman could not be a persona publica, a participant in politics (Hammar 1999, 23-26; Hammar 2000).

A woman's place in the estate of household was also a major place of production in the premodern worldview of the Reformators. Together with the agrarian heritage, Lutheran ideology may have contributed to the creation of a more tolerant atmosphere for women's work and made it less problematic for women to engage in paid labour. However, women's high labour market participation in the Nordic countries does not derive directly from the Lutheran notion of calling, according to which women were to work as mothers, wives, daughters and servants within the estate of oeconomia. In the nineteenth century, when the issue of women's work was rife among the middle classes, this was widely debated in the Nordic countries (See, for example, Hammar 1999, 82-93; Jallinoja 1983, 57-69). Nevertheless, work as vocation and women's place within the estate of the household on the one hand, and full employment and women's waged work as a norm on the other may not be totally disparate. This is one of the exciting questions we need to study more carefully.

A priesthood of all believers is another central idea in Lutheranism. Dag Thorkildsen states that this idea has promoted a culture of equality in the Lutheran countries. According to Lutheran ideology, men and women were equal before God. In keeping with the Lutheran tradition the Nordic state churches had for centuries provided the whole population with the rudiments of learning. Basic education was not differentiated between the sexes. To be equal before God does not, however, imply that women and men were socially equal. Quite the opposite, the Lutheran gender construction was clearly hierarchical. This was one of the issues raised by the early women's movement. In Sweden the editors of Tidskrift for bemmet claimed that the Church of Sweden was "far from Christian" in its understanding of women (Hammar 2000, 44). The contradiction of equality before God and inequality in society can also be seen as a productive element in nineteenth century debates on gender relations and social issues. Additionally, social inequality determined social classes. Lutheran tradition carries both a radical message of equality and a conservative message of gender and class hierarchies.

The relationship between Lutheranism and the principle of universalism is a challenging issue. In a gender perspective it becomes even more stimulating and also complicated. I find Tim Knudsen's discussion on early welfare institutions both inspiring and thought-provoking. As important factors promoting the idea of state social responsibilities he mentions the early development of literacy, local welfare institutions, a local administration involving peasants, and strong social-liberal peasant parties in the nineteenth century. ${ }^{4}$ Literacy was important because in the Lutheran ideology 
everyone should be able to read the Bible. In this respect women and men were equal; it was the equality before God that was in question. Local welfare institutions also included women as recipients of poor relief. In the eighteenth century both Denmark and Sweden clearly defined local responsibilities for poor relief and the care of the disabled. "Traditional universalism" included women and men. However, the role of local self-government is more problematic. Local meetings (sockenstämma in Sweden and Finland) belonged to the estate of politia and were thus reserved for men. The Swedish and Finnish peasants who learned to exercise political decision-making in local meetings were men. In a gender perspective this is not an inclusive factor leading directly to the principle of universalism in the welfare state. Furthermore, as a Finnish peculiarity it needs to be mentioned that it was only in 1917 that women in Finland got an equal right to vote and stand as candidates in local elections (1906 in national elections). Women's road to local politics turned out to be quite a complicated issue. To sum up: women were simultaneously both inside and outside of these institutions. This dual nature of women's position can still be traced in Nordic societies although equality has been declared the official principle of the Nordic model.

\section{Discussion}

Gendering the Nordic model of the welfare state is still of vital importance, albeit quite a lot of research has already been done on women and welfare. The structures of the welfare state - including social services, insurance and labour force participation - are gendered. At the turn of the $21^{\text {st }}$ century the relations of the Nordic model and Lutheranism became one of the new issues among scholars. However, it should not become an alternative discourse replacing the issues raised by women's studies and feminist scholars. Scholars who take a gender perspective in the history of the welfare state and those who study the influence of Lutheranism examine interrelated themes. There are several intriguing questions that deserve to be analysed. For example, in gender research, Lutheranism has remained a self-evident and unproblematized aspect of Nordic societies. However, the relationship between Lutheranism and the welfare state deserves a thorough analysis in a gender perspective. It would open up new perspectives in the history of the Nordic welfare states.

Much of the work done on Lutheranism deals with the age of the Reformation, the nineteenth century and the beginning of the twentieth century, i.e. periods before the age of the modern welfare states in the Nordic countries. Tim Knudsen, in particular, has suggested that the Lutheran tradition needs to be given due attention for the understanding of the universalist nature of the Nordic welfare states. He emphasises a long historical perspective in which the influence of Lutheranism will be traced as a root or as a background of the Nordic welfare model. Moreover, the research on philanthropy has underlined the role of women and religious associations as providers of welfare before the Second World War. Religious and philanthropic organisations and institutions have served the welfare state by initiating many social services that were later taken over by the state.

Nevertheless, the more direct influence of the churches on the welfare policies also needs to be analysed. The mixed economy of welfare provision - proposed by Jane Lewis - is relevant for Nordic research on the relationship between gender, religion and welfare. That is why the relationship between the welfare state and the churchbased charitable activities or the role of the church as a provider of welfare is worth studying. The Nordic churches have not necessarily been the most active promoters of the welfare state, but this does not mean that Lutheranism or Lutheran ideology 
would have been entirely hostile to widening the social responsibilities of the state. There have constantly been different opinions - or different theological interpretations - among the leading Lutheran clergy in the Nordic countries. My conclusion is that we need to be historically more specific when we discuss the influence of Lutheranism on the Nordic welfare states. Not only Lutheran churches but also welfare policies are changing phenomena. There is no influence of Lutheranism as such, there are different interpretations of Lutheran theology, different interpretations of welfare states and different interpretations of gender. The historical interplay of Lutheranism, welfare and gender remains a challenging issue for future research.

\section{NOTER}

1. For a gender perspective see, for example, Leira 1992, Lewis 1992, Sainsbury 1994, Sainsbury 1997, Lewis 1997, Bergqvist \& al. 1999, Julkunen 1999, Siim 2000; For Lutheranism see, for example, Raunio 1999; Knudsen 2000; Tønnessen 2000; Anttonen and Sipilä 2000, 48-49. There are different definitions of the welfare state. For me, the Nordic welfare state consists of certain policies typical for the post-Worild War II period, but the history of the Nordic welfare state can be - and must be - studied in a longer historical perspective. 2. Lewis $2000,221-225$. In an article published in 1992 Lewis mentions the crucial relationship between paid work, unpaid work and welfare but does not discuss the mixed economy of welfare (Lewis 1992).

3. Julkunen 1999; For the other Nordic countries see, for example, Knudsen and Waerness 2001; Sainsbury 1997.

4. Knudsen 2000, pp. 39-61. I do not comment on the peasant parties because my knowledge of them is too limited. However, none of the political parties has been very encouraging for women's equal participation. Cf. Lähteenmäki, Markkola and Ramsay 1997.

\section{REFERENCES}

- Anttonen Anneli and Jorma Sipilä, (2000) Suomalaista sosiaalipolitiikkaa. Vastapaino, Tampere. - Bergman Solveig, (2000): “Studying Women's Movements in a Cross-national Perspective: $\mathrm{Di}$ lemmas and Potentialities", in Aino Saarinen, Hilda Rømer Christensen and Beatrice Halsaa (eds.), Women's Movement and Internationalisation: The

“Third Wave”? Oulun yliopistopaino. Oulu.

- Bergqvist Christina \& al. (ed.) (1999): Likestilte demokratier? Kjønn og politikk $i$ Norden. Universitetsforlaget. Oslo.

- Esping-Andersen Gøsta,( 1999) The Three Worlds of Welfare Capitalism. Princeton University Press. Princeton, N.J.:

. Hammar Inger ( 1998): "Några reflexioner kring 'religionsblind' kvinnoforskning", in Historisk Tidskrift $\mathrm{nr} 1$.

- Hammar Inger, 1999): Emancipation och religion. Den svenska kvinnorörelsens pionjärer $i$ debatt om kvinnans kallelse ca 1860-1900. Carlssons, Stockholm.

- Hammar Inger ( 2000a): "From Fredrika Bremer to Ellen Key: Calling, Gender and the Emancipation Debate in Sweden, c. 1830-1900", in Markkola 2000a.

- Heiskanen Markku and Minna Piispa (1998): Usko, toivo, hakkaus. Kyselytutkimus miesten naisille tekemästä väkivallasta. Tilastokeskus. Helsinki. - Jallinoja Riitta (1983): Suomalaisen naisasialiikkeen taistelukaudet (Porvoo-Helsinki-Juva: WSOY. - Jordansson Birgitta and Tinne Vammen (eds.) (1998) Charitable Women. Philanthropic Welfare 1780-1930. A Nordic and Interdisciplinary Anthology. Odense University Press, Odense. - Julkunen Raija (1999): “Gender, Work, Welfare State. Finland in Comparison", in Women in Finland (Helsinki: Otava.

· Knudsen Knud and Kari Waerness, (2001): "National Context, Individual Characteristics and Attitudes on Mother's Employment: A Comparative Analysis of Great Britain, Sweden and Norway", in Acta Sociologica vol. 44, no 1.

- Knudsen Tim (ed.) (2000) Den nordiske protestantisme og velfordsstaten, Aarhus universitetsforlag, Aarhus.

- Kuusipalo Jaana, (1992) "Finnish Women in Politics", in Women in Finland. Otava, Helsinki.

- Leira Arnlaug, ( 1992) Welfare states and working mothers. The Scandinavian experience (Cambridge: Cambridge University Press.

- Lewis Jane (1992) "Gender and the Development of Welfare Regimes", in Journal of European Social Policy vol. 2 , no. 3. 
- Lewis Jane ( 1997) "Gender and Welfare Regimes: Further Thoughts", in Social Politics .

- Lewis Jane, (2000): "Women and Social Citizenship in Twentieth Century Welfare States", in Sølvi Sogner and Gro Hagemann (eds.), Women's Politics and Women in Politics. In Honour of Ida Blom (Oslo, Bergen: Cappelen Akademisk Forlag, Universitetet i Bergen.

. Lützen Karin, (1998): Byen temmes. Kernefamilie, sociale reformer og velgørenhed $i$ 1800-tallets København. Hans Reitzels Forlag, København. - Lähteenmäki Maria, Pirjo Markkola and Alexandra Ramsay (eds.) (1997), Tksi kamari-kaksi sukupuolta. Suomen eduskunnan ensimmäiset naiset, Eduskunnan kirjasto. Helsinki.

- Markkola Pirjo (ed.) (2000); Gender and Vocation. Women, Religion and Social Change in the Nordic Countries, 1830-1940 (Helsinki: SHS, 2000). (Markkola 2000a).

- Markkola Pirjo ( 2000): "Promoting Faith and Welfare. The Deaconess Movement in Finland and Sweden, 1850-1930", Scandinavian Journal of History, vol 25, Nos. 1-2 2000 (Markkola 2000b). - Raunio Antti, (1999): "Suurten kirkkokuntien sosiaalieettinen opetus", in Jaana Hallamaa (ed.), Raban teologia ja Euroopan kirkot. Lopun ajan sosiaalietiikka. Atena Kustannus Oy. Jyväskylä.

- Rosenbeck Bente ( 1998) "Nordic women's studies and gender research", in Drude von der Fehr, Anna G. Jónasdóttir and Bente Rosenbeck (eds.), Is there a Nordic Feminism? Nordic feminist thought on culture and society. UCL Press, London.

- Sainsbury Diane (1998): Gender, equality, and welfare states (Cambridge: Cambridge University Press.

Sainsbury Diane (ed.) ( 1994) : Gendering welfare states. Sage London.

· Salonen Kari, Kimmo Kääriäinen and Kati Niemelä, Kirkko uudelle vuosituhannelle. Suomen evankelis-luterilainen kirkko vuosina 1996-1999. http://www.evl.fi/kkh/ktk/kertomus96-99/. - Seppo Juha,( 1994): "Church-State Relations in Finland", in Pirjo Työrinoja (ed.), The Evangelical Lutheran Church in Finnish Society. Church Council for Foreign Affairs, Helsinki..

- Siim Birte (2000) Gender and Citizenship. Politics and Agency in France, Britain and Denmark (Cambridge: Cambridge University Press, Cambridge.

- Sormunen Eino, (1958) Hyvinvointivaltio ja benkinen elämä. Eräitä ajankohtaisia ongelmia (Pieksämäki: Suomen Kirkon Sisälähetysseura.

. Thorkildsen Dag, )1997): "Religious Identity and Nordic Identity", in Øystein Sørensen and Bo Stråth (eds.), The Cultural Construction of Norden
(Oslo, Stockholm, Copenhagen, Scandinavian University Press, Oxford, Boston. .

- Towards the Common Good. Statement on the Future of the Welfare Society by the Bishops of the Evangelical Lutheran Church of Finland, March 1999. http://www.evl.fi/english/towardscg.htm.

- Tønnessen Aud V. (2000) "Et trygt og godt hjem for alle"?: kirkelederes kritikk av velferdsstaten etter 1945. Tapir akademisk forlag, Tronheim.

. Åmark Klas and Joakim Palme, (1999) "Historia, samhällsvetenskap och välfärdstat i brytningstid", in Välfärdsstat i brytningstid: Historisk-sambällsvetenskapliga studier om genus och klass, ojämlikhet och fattigdom. Sociologisk Forskning: Supplement.

. Østergård Uffe ( 1997): "The Geopolitics of Nordic Identity - From Composite States to Nation-states", in Øystein Sørensen and Bo Stråth (eds.), The Cultural Construction of Norden Scandinavian University Press .Oslo, Stockholm, Copenhagen, Oxford, Boston.

\section{SUMMARY}

It is suggested here that both gender and religion need to be taken seriously in research on the Nordic welfare states. In a gender perspective, Lutheranism has remained an unproblematized aspect of Nordic societies, and in research on Lutheranism and welfare, gender perspective has been overlooked. The more direct influence of the churches on the welfare policies also needs to be analysed. There have constantly been different opinions among the leading Lutheran clergy. It is argued, that we need to be historically specific when we discuss the influence of Lutheranism on the Nordic welfare states. Not only Lutheran churches but also welfare policies are changing phenomena. There is no influence of Lutheranism as such, there are different interpretations of Lutheran theology, different interpretations of welfare states and different interpretations of gender. The historical interplay of Lutheranism, welfare and gender remains a challenging issue for future research.

\section{Pirjo Markkola}

Academy Research Fellow

Department of History

University of Tampere

Finland 